\title{
REFERENCE SECTIONS OF THE PALEOFAUNAL SUBDIVISIONS OF THE FINAL EOPLEISTOCENE AND EARLY NEOPLEISTOCENE IN THE SOUTH OF EASTERN EUROPE
}

\author{
A.I. Krokhmal' \\ (Recommended by doctor of geological-mineralogical sciences V.N. Shelkopljas)
}

Institute of Geological Sciences of NAS of Ukraine, Kiev, Ukraine, E-mail: krohmal1959@ukr.net Candidate of geological sciences, senior research worker.

A new type of reference section, the paleofaunal reference section (PRS), was proposed to denote the most representative section (exposure), complete or partial, that contains a sufficiently informative fossil record characterizing a particular mono- or polytaxonomic faunal complex or association to be used for the purposes of stratigraphy. An integrated analysis of the geological, paleontological and dating evidence on 34 micromammalian localities ( 26 sections) of the Tiraspol faunal complex, ranging from the final Eopleistocene to Early Neopleistocene, was undertaken. Reference sections for paleofaunal subdivisions (complex, association) are allocated. The horizons 2 to 10 of the section Kolkotova balka were designated as the PRS for the Tiraspol faunal complex of small mammals. Also described were PRSs for several mammalian associations: the Karay-Dubina section for Luzanovska, the Protopopovka section for Protopopovka 2 and Protopopovka 1, the Kolkotova Balka section for Kolkotovka, the Utkonosovka section for Tikhonovka, the Krasnoselka 1 section for Krasnoselka, and the Nagornoye 1 section for Nagornoye.

Key words: paleofaunal reference section, Pleistocene, small mammals, faunal complex, faunal association.

\section{ОПОРНІ РОЗРІЗИ ПААЕОФАУНІСТИЧНИХ ПІАРОЗАІАІВ ФІНААЬНОГО ЕОПАЕЙСТОЦЕНУ ТА РАННЬОГО НЕОПАЕЙСТОЦЕНУ ПІВАНЯ СХІАНОÏ ЄВРОПИ}

\author{
O.I. Крохмаль \\ (Рекомендовано д-ром геол.-мінерал. наук В.М. Шовкоплясом)
}

Інститут геологічних наук НАН Украӥни, Київ, Україна, E-mail: krohmal1959@ukr.net Кандидат геологічних наук, старший науковий співробітник.

Запропоновано новий тип опорного розрізу - палеофауністичний опорний розріз (ПОР) найбільш показовий розріз (оголення) або його частина, у відкладах якого достатньо повно представлено комплекс органічних решток, що характеризують моно- або політаксальний фауністичний комплекс чи окрему фауністичну асоціацію, які використовуються для цілей стратиграфії. На основі загальногеологічних, палеонтологічних і спеціальних (датування) методів дослідження проведено аналіз 34 місцезнаходжень (26 розрізів), що містять мікротеріофауну тираспольського фауністичного комплексу фінального еоплейстоцену та раннього неоплейстоцену. Виділено опорні розрізи для палеофауністичних підрозділів (комплекс, асоціація). Горизонти 2-10 розрізу Колкотова балка виокремлені в якості ПОР для тираспольського фауністичного комплексу дрібних ссавців. Описано ПОР для лузанівської (розріз Карай-Дубина), 2- та 1-ї протопопівської (розріз Протопопівка), колкотівської (розріз Колкотова балка), тихонівської (розріз Утконосівка), красносільської (розріз Красносілка 1) і нагорнської (розріз Нагірне 1) теріоасоціацій.

Ключові слова: палеофауністичний опорний розріз, плейстоцен, дрібні ссавці, фауністичний комплекс, фауністична асоціація.

(๖ A.I. Krokhmal', 2014 


\title{
ОПОРНЫЕ РАЗРЕЗЫ ПААЕОФАУНИСТИЧЕСКИХ ПОАРАЗАЕАЕНИЙ ФИНААЬНОГО ЭОПАЕЙСТОЦЕНА И РАННЕГО НЕОПАЕЙСТОЦЕНА ЮГА ВОСТОЧНОЙ ЕВРОПЫ
}

\author{
А.И. Крохмаль \\ (Рекомендовано д-ром геол.-минерал. наук В.Н. Шелкоплясом)
}

Институт геологических наук НАН Украинь,, Киев, Украина, E-mail: krohmal1959@ukr.net Кандидат геологических наук, старший научный сотрудник.

Предложен новый тип опорного разреза - палеофаунистический опорный разрез (ПОР) наиболее показательный разрез (обнажение) или его часть, в отложениях которого достаточно полно представлен комплекс органических остатков, характеризующий моно- или политаксальный фаунистический комплекс или отдельную фаунистическую ассоциацию, которые используются для целей стратиграфии. На основе общегеологических, палеонтологических и специальных (датировки) методов исследования проведен всесторонний геолого-фаунистический анализ 34 местонахождений (26 разрезов), содержащих микротериофауну тираспольского фаунистического комплекса финального эоплейстоцена и раннего неоплейстоцена. Выделены опорные разрезы для палеофаунистических подразделений (комплекс, ассоциация). Горизонты 2-10 разреза Колкотова балка выделены в качестве ПОР для тираспольского фаунистического комплекса мелких млекопитающих. Описаны ПОР для лузановской (разрез Карай-Дубина), 2- и 1-й протопоповской (разрез Протопоповка), колкотовской (разрез Колкотова балка), тихоновской (разрез Утконосовка), красносельской (разрез Красноселка 1) и нагорнской (разрез Нагорное 1) териоассоциаций.

Ключевые слова: палеофаунистический опорный разрез, плейстоцен, мелкие млекопитающие, фаунистический комплекс, фаунистическая ассоциация.

\section{Introduction}

The Stratigraphic Code of Ukraine provides for stratotypes or reference sections for basic stratigraphic subdivisions of the Pleistocene of rank lower than series, as well as for special stratigraphic units [Стратиграфічний..., 2012]. For stratigraphic subdivision of Quaternary sediments, biostratigraphic (zones, subzones) and climate-stratigraphic (climatoliths, stadials) units are mainly used, with the reference sections designated for the former, and the stratotypes for the latter.

When using small mammals for biostratigraphically subdividing heterofacial continental, liman, or marine sediments, the faunal complex is considered as a principal diagnostic unit, and the mammal association is considered as a subordinate unit. After years of research on such complexes and associations, we arrived to a conclusion that the reference sections for these paleofaunal units should be designated. The status of reference sections would allow these sections to be used in unambiguously interpreting the taxonomic composition of paleofaunal units and in identifying their position on the Quaternary Stratigraphic Scale for the south of East- ern Europe. In this paper, we present geological and faunal (micromammalian) characteristics of the paleofaunal reference sections (PRS) (in the earlier version "biostratigraphic standard section (BSS)" [Крохмаль, 2014]) of the final Eopleistocene (Later Calabrian) and Early Neopleistocene (the first half of the lonian).

\section{Materials and methods}

Twenty-six sections (34 micromammalian localities of the Tiraspol faunal assemblage) of the final Eopleistocene and Early Neopleistocene were studied using geological, paleontological and special (dating) methods.

We define the terms "faunal complex" and "mammal association" as follows. The faunal complex of small mammals is a large first-order faunal unit characterized by a temporal complex of micromammalian genera and species that do not recur through time and are at their particular stage of evolutionary advancement in several phyletic lineages. A spatio-temporal structure of the complex is represented territorially at a level not lower the paleozoogeographic province, geochronologically not higher than time, and chronostratigraphically 
not higher than subformation. The mammal association is a second-order faunal unit, which is subordinate to the faunal complex and represents a stage in the spatio-temporal development of the latter. It is identifiable from its characteristic composition of orthostratigraphic species in one or several phyletic lineages of voles. The taxonomic composition of the association is formed on the basis of species diversity in taxonomically close taphocenoses. Within a separate association, the taphocenoses differ from each other in the proportions of background groups of small mammals.

\section{Results and discussion}

The proposed new term, the paleofaunal reference section (PRS), is the most representative section (exposure) or its part, whose deposits demonstrate a sufficiently complete fossil record characterizing a particular mono- or polytaxonomic faunal or floristic complex or association to be used for the purposes of stratigraphy. Studying such sections will enable to determine the geohistorical marks necessatry for stratigraphic and paleogeographic interpretations of the main stages of the Quaternary biotic evolution.
The Tiraspol faunal complex containing seven micromammalian associations has been recognized in the final Eopleistocene and Early Neopleistocene of the south of Eastern Europe on the basis of studying the evolution of small mammals in the region [Крохмаль и др., 2011; Рековец, 1994]. This complex and its associations reflect the stages of the development of ancient biogeocenoses, currently represented by a series of allochronic taphocenoses. Below we designate paleofaunal reference section for these paleofaunal subdivisions and provide descriptions of geological structures and micromammalogical characteristics of the proposed PRSs.

The Tiraspol faunal complex of large mammals has been described on the basis of fossils from alluvial deposits of the terrace $V$ above the Dniester floodplain. A section of the terrace is exposed in Kolkotova balka [Давид и др., 1988]. We designate the composite section of continental deposits of the Kolkotovka terrace as the PRS for the Tiraspol complex of small mammals. In this composite section, the following deposits are present from bottom to top [Крохмаль, Рековец, 2010] (see Figure):

1. Greenish-gray clays, the upper Sarmatian $1.0 \mathrm{~m}$

2. Sands grayish-yellow, fine- and medium-grained passing in the roof layer in coarsegrained with small pebbles. In the sole layer boulders (up to $30 \mathrm{~cm}$ in diameter)

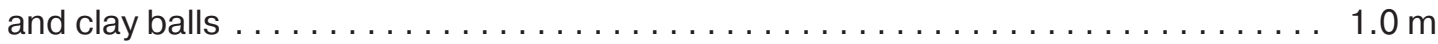

3. Sand-gravel-pebble conglomerate of siliceous and jaspery pebbles. Clay balls of dark brown viscous clay are marked. Collected the remains of mammals and molluscs (Kolkotova balka IV)

4. Bluish-gray clay, viscous, with siliceous and jaspery pebbles, interbeds and inclusion of brown sandy clay are marked. Collected shells of mollusks and ostracods . . . . .

5. Sand-gravel-pebble deposits with lenses and bedset of horizontally and crossbedding medium-grained sand. There are boulders and large clay balls of clay. The top of the stratum is dominated by light gray and brownish-red cross-bedded sands, fine- and medium-grained. Collected the remains of mammals and molluscs

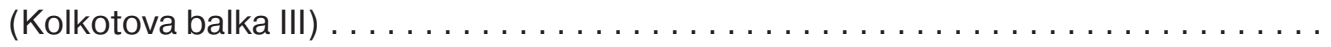

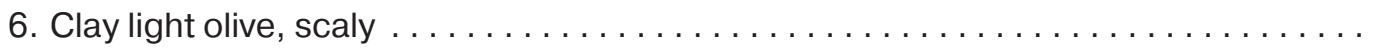

7. Sands from white to light gray, fine- and medium-grained, horizontally and cross-bedded, lenses of clayey sand in the top of layer are marked. Collected the remains of mammals and molluscs (Kolkotova balka III) $\ldots \ldots \ldots \ldots \ldots \ldots \ldots \ldots \ldots \ldots \ldots \ldots$

8. Sands light brown, fine-grained, with interbedded and lenses of silty sand. Collected shells of mollusks and ostracods

9. Clay greenish-gray-brown, sometimes olive, arenated $1.0 \mathrm{~m}$

10. Paleosol, loam reddish brown, in the lower part with carbonate concretions. Layer is broken of shrinkage crack (?), that penetrate into the underlying horizon at a depth

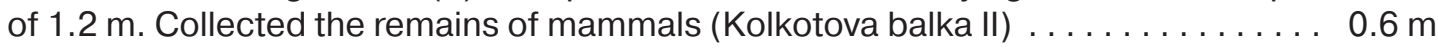


11. Loesslike loam, pale yellow, porous, with calcareous concretions $\ldots \ldots \ldots \ldots \ldots 2.4 \mathrm{~m}$

12. Paleosol, loam dark gray, humic, the chernozem type. Collected the remains of

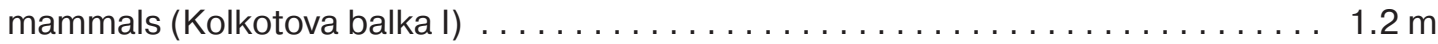

13. Loesslike loam, pale yellow, porous, with calcareous concretions $\ldots \ldots \ldots \ldots .2 \mathrm{~m}$

14. Paleosol, loam dark brown, Layer is broken of shrinkage crack (?) with the filling

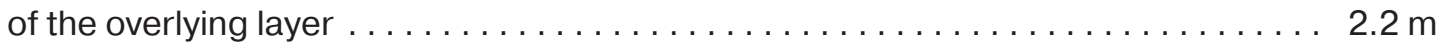

15. Loesslike loam, light brown, porous, with rare calcareous concretions $\ldots \ldots \ldots \ldots 1.0 \mathrm{~m}$

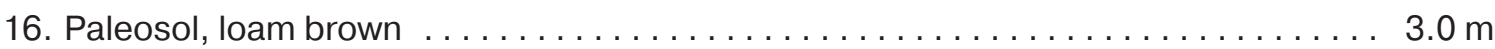

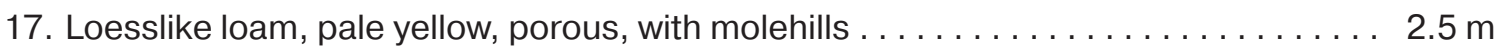

18. Paleosol, loam light brown, with carbonate concretions $\ldots \ldots \ldots \ldots \ldots \ldots \ldots 1.2 \mathrm{~m}$

19. Loesslike loam, pale yellow, porous, with rare calcareous concretions $\ldots \ldots \ldots \ldots .5 \mathrm{~m}$

20. Paleosol, loam light brown $\ldots \ldots \ldots \ldots \ldots \ldots \ldots \ldots \ldots \ldots \ldots \ldots \ldots \ldots \ldots \ldots \ldots \ldots$

21. Loesslike loam, dark yellow, porous, with small calcareous concretions $\ldots \ldots \ldots .4 \mathrm{~m}$

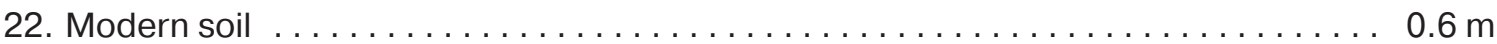
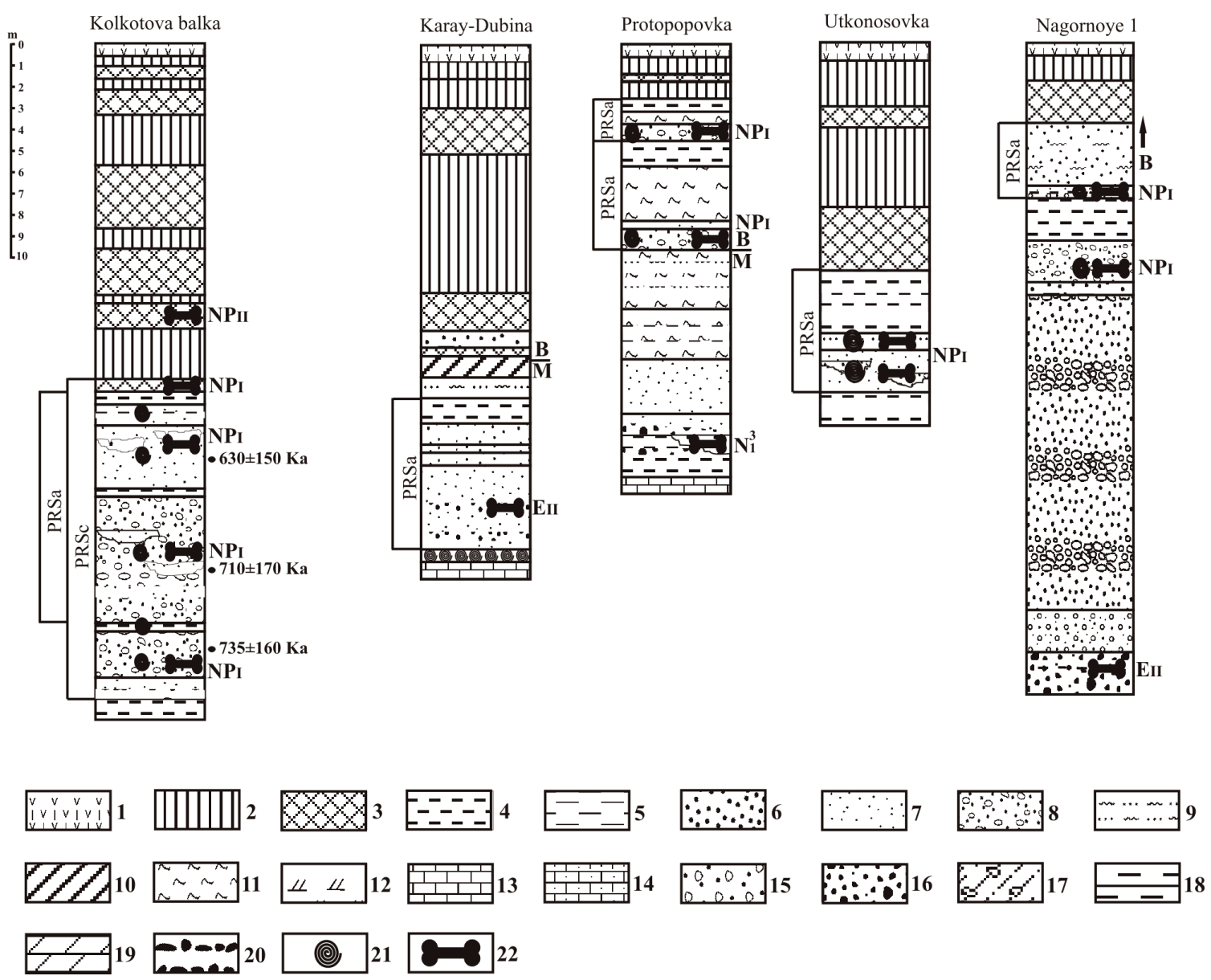

Paleofaunal reference sections (PRS) of the final Eopleistocene and Early Neopleistocene in south of Eastern Europe

Notetion: 1 - modern soil; 2 - loess; 3 - paleosol; 4 - clay; 5 - red-brown clay; 6 - coarse-grained sands; 7 - fine- and medium-grained sands; 8 - sand gravelled; 9 - sandy loam; 10 - loam; 11 - aleurite; 12 - shellstone; 13 - limestone; 14 - conglomerate; 15 - pebble gravel; 16 - gravel; 17 - moraine; 18 - marl; 19 - chalk; 20 - grus; 21 - molluscs; 22 remains of small mammals; E - Eopleistocene; NP - Neopleistocene; B - orthozone Brunnes; M - orthozone Matuyama; $\mathrm{B} / \mathrm{M}$ - boundary of Brunnes-Matuyama; PRSc - paleofaunal reference section of faunal complex; PRSa - paleofaunal reference section of faunal association 
Micromammalian fauna was collected from four localities: Kolkotova balka I (layer 12), Kolkotova balka II (layer 10), Kolkotova balka III (layers 5 and 7), and Kolkotova balka IV (layer 3). The thermoluminescent dates of $735 \pm 160$ and $800 \pm 160$ kya have been obtained for the lower alluvial member, and $710 \pm 170$ and $630 \pm 150$ kya for two horizons of the upper member [Куликов, Чепалыга, 1985]. The PRS proper is the horizons 2-10 of the terrace composite section, which were formed in the beginning of the Martonosha (Ma opolanian) interglacial to the middle of the Lubensk (Ferdynandovian) interglacial.

According to A. David et al. [Давид и др., 1988] and L. Rekovets [Рековец, 1994], the allochronic fauna from two alluvial generations includes the following species:

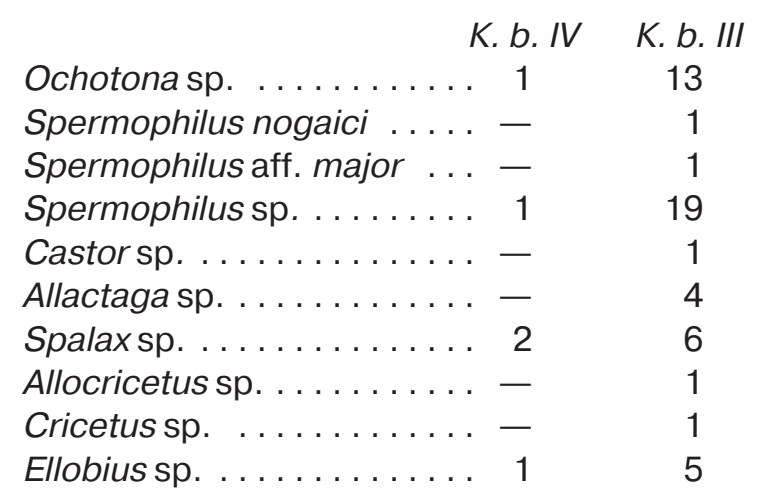

\begin{tabular}{|c|c|c|}
\hline & K. b. IV & K.b. I \\
\hline Clethrionomys glareolus . & . 3 & 14 \\
\hline Prolagurus pannonicus .. & 2 & - \\
\hline Prolagurus posterius . . & - & 14 \\
\hline Eolagurus argyropuloi . & 3 & 12 \\
\hline Mimomys majori . . . . . . . & - & 12 \\
\hline Mimomys intermedius . & 8 & 13 \\
\hline Microtus gregaloides .. & - & 21 \\
\hline Microtus arvalidens .. & 5 & 26 \\
\hline Microtus arvalinus . . . . . & 6 & 44 \\
\hline Microtus protoeconomus & - & 5 \\
\hline
\end{tabular}

The paleosol (Kolkotova balka II) fauna includes [Михайлеску, Маркова, 1992]: Spermophilus sp. (430 remains), Allactaga ex gr. jaculus (2), Spalax microphtalmus (2), Allocricetus ehiki (7), Cricetus cricetus (6), Lagurus transiens (55), Eolagurus luteus (5), Microtus gregalis (7).

During its existence, the Tiraspol faunal complex underwent a series of evolutionary transformations represented by several consecutive mammalian associations. In our view, there were seven associations: Luzanovka, Protopopovka 2, Protopopovka 1, Kolkotovka, Tikhonovka, Krasnoselka, and Nagornoje.

As the PRS for the Luzanovka association, we propose the horizons 3-7 of the terrace section near Karai-Dubina Village, with the following deposits exposed from bottom to top [Маркова, 1982] (see Figure):

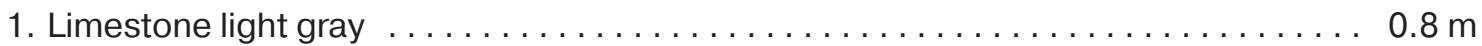

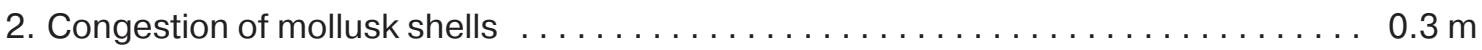

3. Sands white and greenish-gray, cross-bedding, medium-grained, with intercalations and lenses of coarse-grained sand, in which found the remains

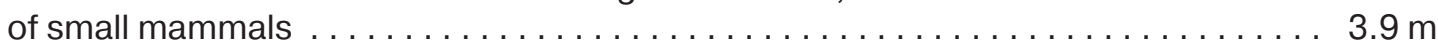

4. Sands of greenish-gray, fine-grained, ferruginate $\ldots \ldots \ldots \ldots \ldots \ldots \ldots \ldots \ldots \ldots$

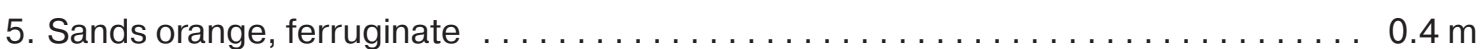

6. Sands light gray, fine-grained, unstratified $\ldots \ldots \ldots \ldots \ldots \ldots \ldots \ldots \ldots \ldots \ldots \ldots$

7. Bluish clay, dense, at the top of the carbonate $\ldots \ldots \ldots \ldots \ldots \ldots \ldots \ldots \ldots \ldots \ldots$

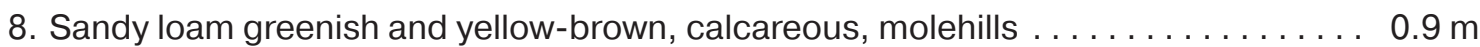

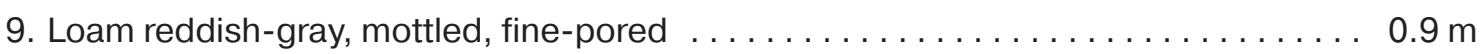

10. Paleosol, blurry, red-brown loam, in the sole of carbonate $\ldots \ldots \ldots \ldots \ldots \ldots \ldots .2 \mathrm{~m}$

11. Sands yellow-brown, clayey, fine- and medium-grained, molehills . . . . . . $0.7 \mathrm{~m}$

12. Paleosol, loam inhomogeneous coloration (reddish), heavy, well presented molehills

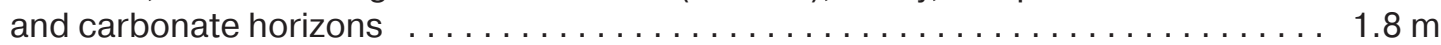

13. Loesslike loam, light pale, in the sole of blue gray. In the layer at a depth of $4.5 \mathrm{~m}$

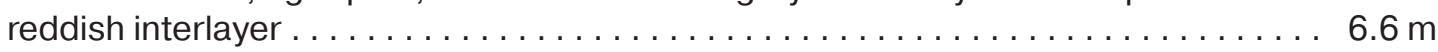

14. Paleosol, loam pinkish-brown, light. Are presented thick (up to $1.0 \mathrm{~m}$ ) illuvial horizon

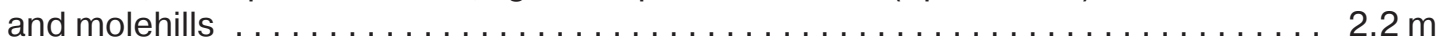




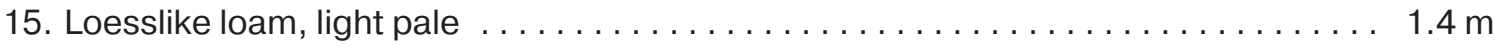

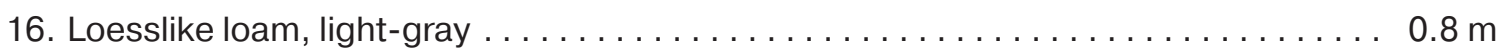

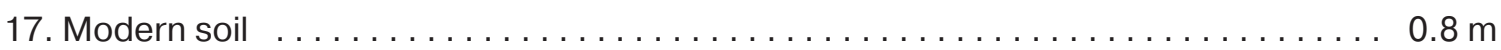

The Brunhes-Matuyama boundary is within the top of loams of the layer $9[\mathrm{Be}-$ личко и др., 1983]. L.I. Rekovets [Рековец, 1994] has identified the following species from interlayers and lenses of coarse-grained sand of the layer 3: Desmana gureevi (31), Sorex sp. (4), Ochotona sp. (10), Lepus sp. (5), Spermophilus sp. (66), Allactaga sp. (11), Spalax sp. (3), Apodemus sylvaticus (1), Apodemus flavicollis (1), Allocricetus bursae (10), Cricetus praeglacialis (44), Clethrionomys glareolus (2), Prolagurus pannonicus (160), Eolagurus argyropuloi (49), Mimomys pusillus (39), Microtus hintoni-gregaloides
(102), Microtus protoeconomus (20), Microtus cf. arvalinus (1).

Two next associations of small mammals (Protopopovka 2 and Protopopovka 1) derive from differently aged horizons of a terrace section near Protopopovka Village. We designate the horizons 7-10 as the PRS for the Protopopovka 2 association, and the horizons 1113 as the PRS for the Protopopovka 1 association. The lower boundary of the Brunhes orthozone is at the bottom of the layer 7 . In the coastal steep, the following deposits are exposed from bottom to top [Рековец, 1994; Крохмаль, Рековец, 2010] (see Figure):

1. Limestone $0.8 \mathrm{M}$

2. Clay bluish, heavy, at the top of $(0.5 \mathrm{~m})$ with intercalations and lenses gray clayey gravelstone to which finds of microtheriofauna are confined (location Protopopovka III, Meotian)

$2.0 \mathrm{M}$

3. Sands gray, unstratified, in the sole gravelled $\ldots \ldots \ldots \ldots \ldots \ldots \ldots \ldots \ldots \ldots \ldots$

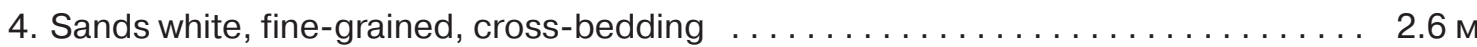

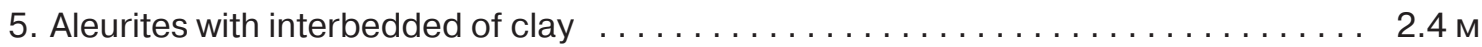

6. Interbedding of light sandy loam and aleurites, horizontal bedding, upper contact

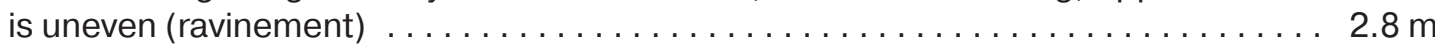

7. Sands gravelled with inclusions of pebbles, light, with the fauna of small mammals

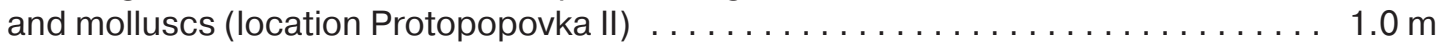

8. Sands white and yellow, fine-grained $\ldots \ldots \ldots \ldots \ldots \ldots \ldots \ldots \ldots \ldots \ldots \ldots \ldots \ldots \ldots$

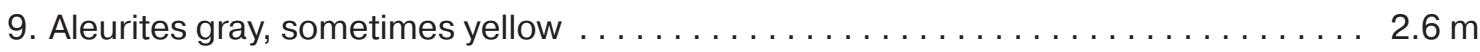

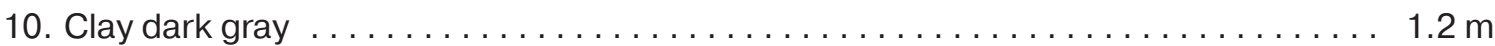

11. Sands and gravelstones with the remains of small mammals and molluscs, lower and upper bounds with traces of erosion (location Protopopovka I) $\ldots \ldots \ldots \ldots . .8 \mathrm{~m}$

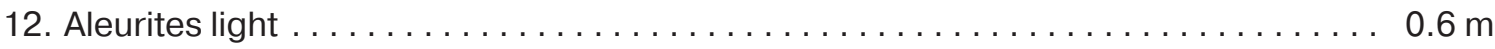

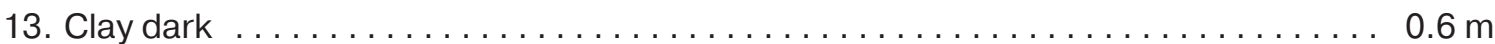

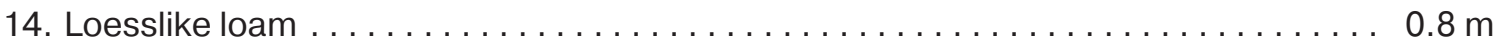

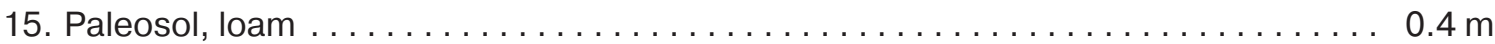

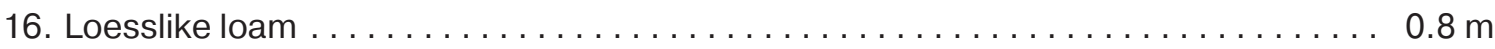

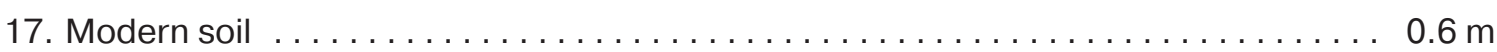

The layer 7 (Protopopovka II) and layer 11 (Protopopovka I) have yielded the following micromammals [Рековец, 1994; Rekovets, Nadachowski, 1995]:

\begin{tabular}{|c|c|c|}
\hline & P. II & P. \\
\hline Sorex sp. & 2 & - \\
\hline Desmana sp. . . . . . . . . . . & 8 & 11 \\
\hline Lepussp. . . . . . . . . . . . & 1 & \\
\hline
\end{tabular}

\begin{tabular}{|c|c|c|}
\hline & P. II & P. \\
\hline Ochotona sp. & 1 & 6 \\
\hline Sciurotamias sp. . . . . . . . . & 3 & - \\
\hline Spermophilus nogaici . . . . . . . . & 16 & 11 \\
\hline Allactaga sp. . . . . . . . . & - & 2 \\
\hline Spalax sp. . . & 3 & 1 \\
\hline Apodemus sp. . . . . . . . . . & 4 & 3 \\
\hline Allocricetus bursae . . . . . . . . & 10 & 1 \\
\hline
\end{tabular}




\begin{tabular}{|c|c|c|c|}
\hline & P. II & P. I & As the PRS for the Kolkotovka association, we \\
\hline Cricetus praeglacialis & 5 & 6 & propose the horizons $5-9$ of the main section \\
\hline Ellobius palaeotalpinus . & 2 & - & of the Kolkotovka terrace, the locality Kolko- \\
\hline Clethrionomys glareolus . . . . . . & 4 & 4 & tova balka III. This is a so-called "main horizon \\
\hline Villanyia fejervaryi ........... & 7 & - & of Tiraspol gravel". \\
\hline Villanyia petenyii . & - & 1 & The Tikhonovka association of the Tiraspol \\
\hline Villanyia newtoni & 1 & - & faunal complex has been established from the \\
\hline Lagurodon arankae . & 2 & 3 & fauna of the locality Tikhonovka 1 [Рековец, \\
\hline Prolagurus pannonicus .... & 12 & - & . As the PRS for this association, we pro- \\
\hline Prolagurus posterius ..... & - & 16 & the layers 2-4 of the exposure near \\
\hline Eolagurus argyropuloi . ........ & 5 & 5 & Odessa Region), be- \\
\hline Mimomys pusillus . ......... & 4 & 3 & hologically poorly pronounced owing to \\
\hline Mimomys intermedius ....... & 5 & 1 & its being leaned against or superimposed on \\
\hline Allophaiomys pliocaenicus .... & 5 & - & more ancient terraces [Крохмаль, Рековец, \\
\hline Microtus hintoni-gregaloides . . & 5 & 22 & 2010]. The following rocks are exposed from \\
\hline Microtus protoeconomus ... & 6 & - & bottom to top of the Utkonosovka section [Mи- \\
\hline Microtus arvalidens . . . . . & 4 & - & хайлеску, Маркова, 1992; Константинова, \\
\hline Microtus arvalinus . . . . . . . . . & 3 & 15 & 1967] (see Figure): \\
\hline
\end{tabular}

1. Clay yellow, with interbedded of sandy loam $\ldots \ldots \ldots \ldots \ldots \ldots \ldots \ldots \ldots \ldots \ldots \ldots$

2. Sands light gray, fine-grained, sometimes ferruginate, with lenses of gravelstones. Is present fauna of small mammals, brackishwater and freshwater molluscs . . . . . $2.0 \mathrm{~m}$

3. Sandy loams gray, horizontal bedding, with remains of small mammals, brackishwater

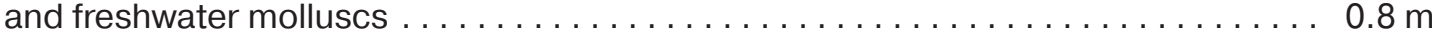

4. Clay greenish-bluish, horizontal bedding, with interbedded of sandy loam, at the top of layer manganese concretions are present. In interbeds are marked the large shells

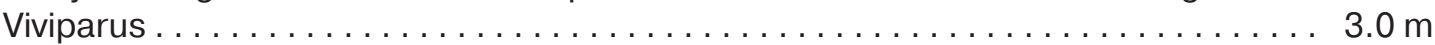

5. Paleosol hydromorphic, dark gray, with calcareous concretions, druses of gypsum and ferrugination nuclei in the middle and bottom of layer $\ldots \ldots \ldots \ldots \ldots \ldots .0 \ldots$

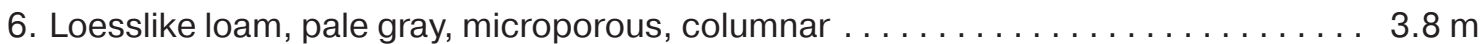

7. Paleosol, loam dark, slightly carbonate, sometimes gypsinate with rare molehills . . $1.0 \mathrm{~m}$

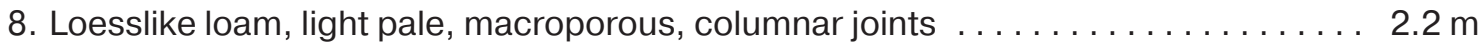

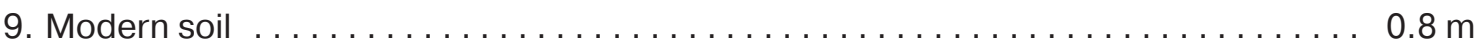

The shells collected from the liman-alluvial member of the terrace (layers 2 and 3 ) are characteristic of the Chauda basin [Михайлеску, Маркова, 1992]. Micromammals include the following species [Михайлеску, Маркова, 1992; Константинова, 1967]: Sorexsp., Ochotona sp., Spermophilus sp., Prolagurus posterius, Lagurus transiens, Eolagurus luteus, Mimomys intermedius, Microtus arvalidens, Microtus gregaloides, Microtus arvalinus, Microtus oeconomus.
As the PRS for the Krasnoselka association, we propose an exposure near Krasnoselka Village (Odessa Region), where Quaternary deposits formed several terraces of different ages [Веклич, 1968; Веклич, Сиренко, 1972; Возгрин, 2004]. The PRS Krasnoselka 1 is a section of the earliest terrace on the outskirts of the village. It demonstrates the following deposits from bottom to top:

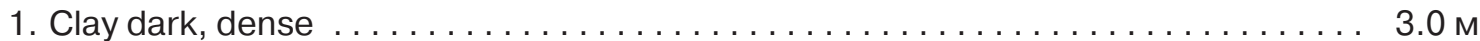

2. Gravelite light, clayey, coarse-grained, with numerous calcareous concretions. Contains the remains of small mammals $\ldots \ldots \ldots \ldots \ldots \ldots \ldots \ldots \ldots \ldots \ldots \ldots$

3. Loess and loesslike loam with several horizons of paleosol $\ldots \ldots \ldots \ldots \ldots \ldots \ldots .0 \ldots$

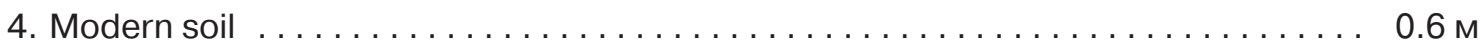


Alluvial deposits of the layer 2 have yielded the following small mammals [Рековец, 1994]: Pliolagomys kujalnikensis (3), Ochotona lazari (4), Spermophilus sp. (21), Castor sp. (1), Allactaga sp. (1), Spalax sp. (2), Apodemus flavicollis (2), Allocricetus bursae (6), Ellobius sp. (2), Prolagurus posterius (2), Lagurus transiens (8), Eolagurus luteus (8), Mimomys reidi (2), Mimomys pusillus (2), Mimomys sp. (1), Microtus gregalis (1), Microtus oeconomus (2), Microtus arvalidens (1), Microtus arvalinus (5).
A final association of the Tiraspol faunal complex is the Nagornoye mammal association. As its PRS, we designate the horizons 7-8 of the main section of the terrace $V$ above the Danube floodplain (Nagornoye 1), which is in a sand quarry on the southern outskirts of Nagornoye Village (Odessa Region). The following deposits are exposed from bottom to top [Крохмаль, Рековец, 2010; Ратников, Крохмаль, 2005] (see Figure):

1. Gravel with interbedded ferruginous clays and greenish-gray sand with gray sandstone, with rare small mammal bones (location Nagornoye 1, III). Contact with socle of terraces abrupt . . . . . . . . . . . . . .

2. Sands light gray, inequigranular, diagonal and horizontal bedded with interbedded

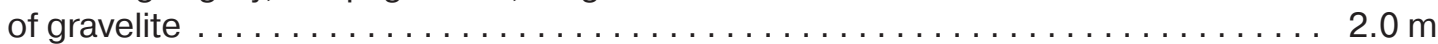

3. Sands light gray from fine- to inequigranular, raveling, micaceous with lenses of gravel, by bedding in the sand sequence the horizons of millstone grit and gravelstones

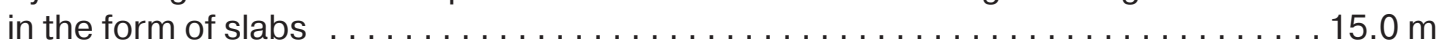

4. Sands of light gray, fine-grained, interbedded with clay $\ldots \ldots \ldots \ldots \ldots \ldots \ldots .5 \mathrm{~m}$

5. Sands light gray, micaceous, inequigranular, cross-bedded with gravel and rare molIuscs Viviparus, Dreissena, Theodoxus and others, as well as rare bones of small

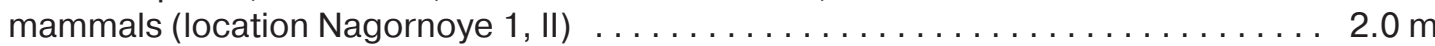

6. Grayish-green clay, dense, horizontal bedded $\ldots \ldots \ldots \ldots \ldots \ldots \ldots \ldots \ldots \ldots \ldots$

7. Sands of gray, fine-grained, clayey, horizontal and cross-bedding, with gravelstones and diverse fauna of molluscs and small vertebrates (Iocation Nagornoye 1, I) $\ldots . .5 \mathrm{~m}$

8. Sands and aleurites greenish-gray, ferruginizated $\ldots \ldots \ldots \ldots \ldots \ldots \ldots \ldots \ldots . \ldots \ldots$

9. Paleosol, dense silty clay, reddish-brown $\ldots \ldots \ldots \ldots \ldots \ldots \ldots \ldots \ldots \ldots \ldots \ldots \ldots$

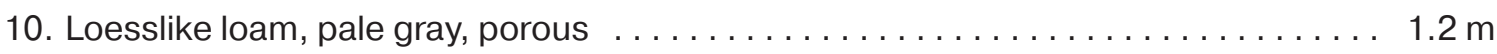

11. Modern soil $\ldots \ldots \ldots \ldots \ldots \ldots \ldots \ldots \ldots \ldots \ldots \ldots \ldots \ldots \ldots \ldots \ldots \ldots \ldots$

PRS presented 7 and 8 horizons of the main section. The stratum of liman sediments of the terrace (the layers 4-8) has normal magnetization of the Brunhes orthozone [Михайлеску, Маркова, 1992]. A reach fauna of freshwater mollusks together with Didacna baericrassa has been collected from the layer 7 [Михайлеску, Маркова, 1992; Гожик, 2006]. Nagornoye $1, I$ has also produced 75 bone fragments of the herpetofauna representing seven families: Triturus cristatus Laur., Bombina bombina L., Pelobates fuscus Laur., Pelobates sp., Bufo raddei Str., Bufo (bufo) sp., Bufo sp., Rana ridibunda Pall., Rana (esculenta) sp., Rana (temporaria) sp., Rana sp., Anura indet.; Lacerta cf. agilis L., Colubrinae indet., Natrix natrix L., Natrix sp., Serpentes indet. [Ратников, Крохмаль, 2005].
From the layer 7 (Nagornoye 1,I), the following species of small mammals have been identified [Крохмаль, 1991; Крохмаль, Дыкань, 2006]: Sorexcf. runtonensis (1), Sorex cf. subaraneus (1), Crocidurasp. (2), Talpa cf. fossilis (2), Desmana sp. (2), Ochotona sp. (1), Spermophilus sp. (31), Allactagasp. (1), Spalax sp. (1), Cricetus sp. (2), Allocricetus sp. (1), Apodemus sp. (1), Ellobius sp. (5), Clethrionomys ex gr. glareolus (3), Prolagurus posterius (2), Eolagurus luteus (1), Mimomys intermedius (8), Arvicola mosbachensis (50), Microtus gregaloides (2), Microtus arvalidens (34).

\section{Conclusions}

1. The new term "paleofaunal reference section" (PRS) is proposed and defined as the most representative section (exposure), complete or partial, that contains a sufficiently in- 
formative fossil record characterizing a particular mono- or polytaxonomic faunal or floristic complex or association to be used for the purposes of stratigraphy.

2. The horizons 2-10 of the section Kolkotova balka are designated as the PRS for the Tiraspol faunal complex of small mammals. Within this complex, the PRSs for seven mammalian associations are also designated: the Karay-Dubina section for the Luzanovska association, the Protopopovka section for the Protopopovka 2 and Protopopovka 1 associations, the Kolkotova Balka section for the

\section{References}

1. Веклич М.Ф. Стратиграфия лессовой формации Украины и соседних стран. Киев: Наук. думка, 1968. 238 с.

Veklich M.F., 1968. Stratigraphy of loess formation of Ukraine and neighboring countries. Kiev: Naukova Dumka, 238 p. (in Russian).

2. Веклич М.Ф., Сиренко Н.А. Опорные геологические разрезы антропогена Украины. Киев: Наук. думка, 1972. Ч. 3. 228 с.

Veklich M.F., Sirenko N.A., 1972. Reference geological sections of Anthropogene of Ukraine. Kiev: Naukova Dumka, part 3, 228 p. (in Russian).

3. Величко А.А., Маркова А.К., Певзнер М.А., Ударцев В.П. Положение границы магнитной полярности Матуяма-Брюнес в хроностратиграфической шкале континентальных отложений Восточной Европы. Докл. АН СССР. 1983. Т. 269, № 5. С. 1147-1150.

Velichko A.A., Markova A.K., Pevzner M.A., Udartsev V.P., 1983. The position of the magnetic polarity of the Matuyama-Brunhes in chronostratigraphic scale of continental deposits in Eastern Europe. Doklady AN SSSR, vol. 269, No. 5, p. 11471150 (in Russian).

4. Возгрин Б.Д. Використання мікротеріологічного методу при стратиграфічному розчленуванні четвертинних відкладів. В кн.: Проблеми стратиграфії фанерозою України. Київ, 2004. C. 263-265.

Vozgrin B.D., 2004. Use of microtheriologic method for stratigraphic dismemberment of Quaternary sediments. In: Problems of Phanerozoic stratigraphy of Ukraine. Kyiv, p. 263-265 (in Ukrainian).

5. Гожик П.Ф. Пресноводные моллюски позднего кайнозоя юга Восточной Европы. В 2 ч. ч. I. Надсемейство UNIONOIDEA. Киев, 2006. $280 \mathrm{c}$.

Gozhik P.F., 2006. Freshwater molluscs of Late Cenozoic from south of Eastern Europe. In 2 parts.
Kolkotovka association, the Utkonosovka section for the Tikhonovka association, the Krasnoselka 1 section for the Krasnoselka association, and the Nagornoye 1 section for the Nagornoye association.

3. Geological structures of the proposed PRSs are described in detail, and the corresponding micromammalian faunal lists are presented. The succession of small mammal associations of the Tiraspol faunal complex suggests that the micro- and macroevolutionary processes in their taxa were irreversible and strictly directed.

Part I. The superfamily UNIONOIDEA. Kiev, $280 \mathrm{p}$. (in Russian).

6. Давид А.И., Волошина М.И., Негадаев-Никонов К.Н., Медяник С.И., Шушпанов К.И., Редкозубов О.И. Палеоценозы раннего плейстоцена нижнего Приднестровья / отв. ред. А.Н. Лунгу. Кишинев: Штиинца, 1988. 106 с.

David A.I., Voloshina M.I., Negadaev-Nikonov K.N., Medjanik S.I, Shushpanov K.I., Redkozub O.I., 1998. Paleocenosis of Early Pleistocene of lower Transdnistria / Ed. A.N. Lungu. Kishinev: Shtiintsa, 106 p. (in Russian).

7. Константинова Н.А. Антропоген южной Молдавии и юго-западной Украины / отв. ред. К.В. Никифорова. Москва: Наука, 1967. 140 с. (Тр. ГИН АН СССР; Вып. 173).

Konstantinova N.A., 1967. Anthropogene the southern Moldova and southwestern Ukraine / Ed. K.V. Nikiforova. Moskow: Nauka, 140 p. (Trudy GIN AN SSSR; Iss. 173) (in Russian).

8. Крохмаль А.И. Микротериофауна V надпойменной террасы Дуная и ее стратиграфическое положение. В кн.: Антропогеновые (четвертичные) формации Украины: Сб. науч. тр. Киев, 1991. C. 87-92.

Krokhmal' A.I., 1991. Microtheriofauna of V terrace above the floodplain of the Danube and its stratigraphic position. In: Anthropogen (Quaternary) formation of Ukraine: Compilation of scientific transactions. Kiev, p. 87-92 (in Russian).

9. Крохмаль А.И. Опорные биостратиграфические разрезы палеофаунистических подразделений эоплейстоцена юга Восточной Европы. Buletinul Institutului de Geologie si Seismologie al ASM. 2014. № 1. C. 94-104.

Krokhmal' A.I., 2014. Reference biostratigraphic sections of the paleofaunal subdivisions of the Eopleistocene in the south of Eastern Europe. Buletinul Institutului de Geologie si Seismologie al ASM, № 1, p. 94-104 (in Russian). 
10. Крохмаль А.И., Дыкань Н.И. Биостратиграфическая корреляция среднеплейстоценовых отложений Центральной и Восточной Европы (на примере разрезов Украины, Германии и России). Сучасні напрямки української геологічної науки: Зб. наук. пр. ІГН НАН України. Київ, 2006. C. 232-239.

Krokhmal' A.I., Dykan N.I., 2006. Biostratigraphic correlation of Middle Pleistocene deposits of Central and Eastern Europe (for example, sections of the Ukraine, Germany and Russia). Modern directions of Ukrainian geological science: Compilation of scientific transactions of IGS of NAS of Ukraine. Kyiv, p. 232-239 (in Russian).

11. Крохмаль А.И., Рековец Л.И. Местонахождения мелких млекопитающих плейстоцена Украины и сопредельных территорий. Киев: LAT \& K, 2010. $330 \mathrm{c}$.

Krokhmal' A.I., Rekovets L.I., 2010. Locations of Pleistocene small mammals of Ukraine and adjacent territories. Kiev: LAT \& K, 330 p. (in Russian).

12. Крохмаль А.И., Шелкопляс В.Н., Комар М.С., Дыкань Н.И., Прилипко С.К., Рудюк В.В., Христофорова Т.Ф. Комплексное обоснование объема и границ стратиграфических подразделений плейстоцена Украины. Геол. журн. 2011. № 3 (336). C. 7-25.

Krokhmal' A.I., Shelkoplas V.N., Komar M.S., Dykan' N.I., Prylypko S.K., Rudjuk V.V., Khrystoforova T.F., 2011. Comprehensive substantiation of volume and boundaries of Pleistocene stratigraphic units of Ukraine. Geologichnyy zhurnal, No. 3 (336), p. 7-25 (in Russian)

13. Куликов О.А., Чепалыга А.Л. Хронология террас Днестра по данным биостратиграфии и термолюминесцентного метода. В кн.: Геохронология четвертичного периода. Таллинн: Изд-во АН ЭССР, 1985. С. 52-53.

Kulikov J.A., Chepalyga A.L., 1985. Chronology of Dniester terraces according biostratigraphy and thermoluminescent method. In: Geochronology of the Quaternary period. Tallinn: Izdatel'stvo AN JeSSR, p. 52-53 (in Russian).

14. Маркова А.К. Плейстоценовые грызуны Русской равнины (их значение для палеогеогра- фии и стратиграфии) / отв. ред. А.А. Величко. М.: Наука, 1982. 186 с.

Markova A.K., 1982. Pleistocene rodents of Russian plains (their importance for paleogeography and stratigraphy) / Ed. A.A. Velichko. Moskow: Nauka, 186 p. (in Russian).

15. Михайлеску К.Д., Маркова А.К. Палеогеографические этапы развития фауны юга Молдовы в антропогене (мелкие млекопитающие и моллюски). Кишинев: Штиинца, 1992. 312 с.

Mikhaylesku K.D., Markova A.K., 1992. Paleogeographic development stages of fauna in the south of Moldova Antropogene (small mammals and molluscs). Kishinev: Shtiintsa, 312 p. (in Russian).

16. Ратников В.Ю., Крохмаль А.И. Среднеплейстоценовые мелкие наземные позвоночные разрезов Нагорное-1 и Нагорное-2. Геол. журн. 2005. № 4 (314). C. 97-105.

Ratnikov V.Ur., Krokhmal' A.I., 2005. Middle Pleistocene small terrestrial vertebrates in sections Nagornoye-1 and Nagornoye-2. Geologichnyy zhurnal, No. 4 (314), p. 97-105 (in Russian).

17. Рековец Л.И. Мелкие млекопитающие антропогена юга Восточной Европы / отв. ред. В.А. Топачевский. Киев: Наук. думка, 1994. 370 с.

Rekovets L.I., 1994. Small mammals of the Anthropogene south of Eastern Europe / Ed. V.A. Topachevsky. Kiev: Naukova Dumka, 370 p. (in Russian).

18. Стратиграфічний кодекс України / відп. ред. П.Ф. Гожик. Київ, 2012. 66 с.

Stratigraphic Code of Ukraine, 2012 / Ed. P.F. Gozhik. Kyiv, 66 p. (in Ukrainian).

19. Rekovets L., Nadachowski A. Pleistocene Voles (Arvicolidae) of the Ukraine. Paleontologia $i$ Evolucio. 1995. № 28-29. P. 145-245.

Rekovets L., Nadachowski A., 1995. Pleistocene Voles (Arvicolidae) of the Ukraine. Paleontologia i Evolucio, № 28-29, p. 145-245 (in English).

Received June 6, 2014 